\title{
Flow partitioning and unstable divergence in fluviokarst evolution in central Kentucky
}

\author{
J. D. Phillips ${ }^{1}$ and M. D. Walls ${ }^{2}$ \\ ${ }^{1}$ Tobacco Road Research Team, Department of Geography, University of Kentucky, Lexington, KY 40506-0027, USA \\ ${ }^{2}$ PlanGraphics, Inc., 112 E. Main St., Frankfort, KY 40601-2314, USA
}

Received: 5 May 2004 - Revised: 27 June 2004 - Accepted: 3 August 2004 - Published: 20 August 2004

Part of Special Issue "Nonlinear deterministic dynamics in hydrologic systems: present activities and future challenges"

\begin{abstract}
In fluviokarst landscapes flow may be partitioned into its surface and subsurface components as well as into diffuse and concentrated flow. The competition among these is hypothesized to be responsible for the divergence of the landscape in a fluviokarst region of central Kentucky into depression-rich, unchannelled karst-rich and channel-poor (KRCP) and strongly fluvially dissected channel-rich karstpoor (CRKP) zones. The interrelationships between diffuse surface runoff, channelized surface flow, diffuse recharge, and point recharge are dynamically unstable and chaotic, implying that small changes in the partitioning are likely to have disproportionately large and long-lived impacts, reflected in geomorphology. In the Kentucky River gorge, rapid Quaternary incision has resulted in local slope changes which should induce instability in the flow partitioning system. A GIS-based landscape classification scheme showed that there is a relationship between slope gradients and the degree of karstification or fluvial dissection. Geomorphic interpretation of landforms in the river gorge area indicates that CRKP and KRCP zones are growing at the expense of other landscape classes. This results in an increase in Kolmogorov entropy, a characteristic of a dynamically, unstable, chaotic system. Results support the hypothesis that divergent landscape evolution is linked to the complex nonlinear dynamics of low partitioning.
\end{abstract}

\section{Introduction}

Studies of nonlinear dynamics in hydrology are typically based on the analysis of time series of phenomena such as stream discharge, precipitation, or water levels (for reviews and examples see Sivakumar, 2000; 2004; Zhou et al., 2002; Lall et al., 1996; Islam and Sivakumar, 2002; Porporato and Ridolfi, 1997; Baker and Brunsdon, 2003). Hydrologic changes and hydrologic system evolution may occur over

Correspondence to: J. D. Phillips

(jdp@uky.edu) very long temporal scales, however. Palaeohydrologists, and earth scientists obliged to deal with hydrologic forcings of geomorphic, sedimentary, and other geosystems, often do not have long time series data to work with. The study of nonlinear dynamics at these time scales moves away from statistical analysis of time series to the deployment of methods of the historical and interpretive geosciences to detect and analyze the signatures of complex nonlinear dynamics. This paper takes the latter approach. Field observations of fluviokarst landscapes in the Kentucky study area suggested a hypothesis that complex nonlinear relationships involving the partitioning of flow are responsible for the apparent divergence of the landscape into zones completely dominated by either karst or fluvial features rather than the mix usually encountered in fluviokarst, and that the divergence is driven by local changes in slope. We used a qualitative system model to test for dynamical instability and chaos in the flow partitioning system, and analysis of the spatial correspondence of landscape types and slope classes to test for the hypothesized slope influences. Geomorphic interpretation of fluvial and karst landforms in a portion of the study area known to have experienced significant Quaternary downcutting was used to establish the landscape transitions underway. This in turn was linked to Kolmogorov entropy as an indicator of deterministic chaos. By combining the methods of nonlinear dynamical systems analysis, spatial analysis, and field geomorphology, addressing the nonlinear dynamics of hydrologic and geomorphic systems over landscape evolution time scales is possible.

\subsection{Fluviokarst hydrology and geomorphology}

Many carbonate terranes are characterized by a mixture of hydrologic pathways and associated landforms reflecting both fluvial, surface-dominated flow and karst, subsurfacedominated flow. Some of these fluviokarst systems not only feature the presence of both fluvial and karst features, but also show evidence of bimodality. That is, wherever topography is highly eroded, it is characterized by zones of 
(1) fluvially-dissected areas with few or no karst features evident at the surface or (2) intense dissolutional, karst development dominated by dolines and other depressions, with little or no evidence of surface flow or fluvial landsculpting. Some of these karst- or channel-dominated zones are apparently related to lithological, structural, or regional topographic controls, but in others karst/fluvial divergence occurs where there are no obvious geological controls. In this paper we develop a model of the interactions between surface/subsurface flow partitioning, karstification, fluvial dissection, and topographic slope in an effort to explain the bimodal, divergent topography in the central Kentucky Inner Bluegrass karst region.

Karst landscapes may have intermittent, sparselydistributed or undetectable surface drainage due the diversion of surface flow underground. However, in many cases both surface and subsurface drainage features are often present in a mixture called fluviokarst. Coexistence of fluvial and karst drainage features is controlled by the thickness and spatial distribution of soluble lithologies. Transitions may occur as karst areas are transformed to fluvial domination due to plugging of subsurface conduits, stripping of soluble rock, or exhumation and capture of subsurface drainage by fluvial erosion. Fluvial-to-karst transitions may occur as karst depressions capture surface drainage, or due to dissolution in channels. The relative importance of fluvial and karst forms and processes is sensitive to local environmental constraints such as the extent to which channelized flows are delivered from adjacent nonkarst terrains, lithology, structure, climate, biotic influences, and geomorphic history. Reviews of these ideas are provided in several books on karst geomorphology and hydrology (Dreybrodt, 1988; Jennings, 1985; White, 1988; Ford and Williams, 1989).

The development of solutional depressions in karst is a canonical geomorphological example of finite selfreinforcing growth. Once a depression is initiated, it tends to capture and hold more moisture, intensifying chemical weathering, and so forth until limited by external controls (for example non-soluble lithology), competition for moisture, or downward moisture movement into, for example, fractures or subsurface caverns. The growth of karstic depressions (and weathering depressions more generally) has been explicitly linked to dynamical instability (Scheidegger, 1983; Viles, 2001). Likewise, the initiation of channelized surface drainage may be characterized by positive feedback (once initiated, channels collect more flow, increasing shear stress and enlarging or extending the channel). In some cases channel initiation has also been explicitly linked to dynamical instability (Smith and Bretherton, 1972; Loewenherz, 1991; Dietrich et al., 1992). In either case the selfreinforcement is finite due to limitations such as the extent or thickness of soluble rock in the case of karst depressions, or the production of runoff in the case of channels.

This leads to the hypothesis that minor perturbations, or variations in initial topography, may lead to a domination of either karst or fluvial erosion, and that once initiated, either tends to be persistent and self-reinforcing. This would lead to the landscape patterns observed in the study area; divergence into karst-rich channel-poor (KRCP) and channel-rich karstpoor (CRKP) zones.

\section{Dynamical instability in fluviokarst systems}

The dynamical stability of the fluviokarst system can be analyzed using qualitative models. This approach allows only a determination of whether the system is stable or unstable in response to small perturbations or minor variations in initial conditions. However, in this study a key question concerns the possibility that minor variations in topography might determine or reinforce divergence into KRCP and CRKP zones. Despite its lack of specificity, the qualitative model is quite general and robust in that it is not dependent on particular parameter values or model specifics. The interactions among system components are depicted as box-and-arrow models where each arrow (or lack thereof) indicates the positive, negative (or negligible) influence of the components on each other. This is translated into an interaction matrix.

The characteristic equation of the interaction matrix is

$F_{0} \lambda^{n}+F_{\mathrm{X}} \lambda^{n-1}+F_{2} \lambda^{n-2}+\ldots+F_{n-1} \lambda+F_{n}=0$.

$\lambda^{v}$ are the real parts of the complex eigenvalues, which are equivalent to the Lyapunov exponents of the system, and $n$ is the number of components. $F_{k}$ is feedback at level $k$ :

$$
F_{k}=\sum_{m=1}^{i}(-1)^{m+1} Z(m, k),
$$

where $Z(m, k)$ is the product of $m$ disjunct loops with $k$ components. $F_{o}=-1$ by convention.

The $\lambda$ give the rate of system convergence $(\lambda<0)$ or divergence $(\lambda>0)$ following a perturbation, or the rate at which, on average, random pairs of points converge or diverge over time:

$\boldsymbol{x}(t)=\boldsymbol{v} \boldsymbol{C} e^{\lambda t}$,

where $\mathrm{v}$ are the eigenvectors and $\mathrm{C}$ the intial conditions. All quantities above except $t$ are vectors. Of particular interest is the case of $\lambda>1$, where effects of a perturbation grow exponentially over some finite time. If any $\lambda>0$, the system is unstable (all $\lambda<0$ indicates stability). As chaotic systems are defined mathematically on the basis of a positive Lyapunov exponent, dynamical instability is in this case equivalent to deterministic chaos.

According to the Routh-Hurwitz criteria the necessary and sufficient conditions for all real parts of all eigenvalues (and therefore all Lyapunov exponents) to be negative are (Cesari, 1971):

- $F_{i}<0$, for all $i$.

- Successive Hurwitz determinants are positive. For a $n=3$ or $n=4, F_{1} F_{2}+F 3>0$. 
Mathematical details are given by, e.g. Cesari (1971) and Puccia and Levins (1985), and discussions of applications in geomorphology and geophysics by Andronova and Schlesinger (1992), Phillips (1999), Scheidegger (1991) and Slingerland (1981).

\subsection{Flow Competition Model}

While previous work has focussed on the erosional and solutional development of the landscape at a detailed scale within a small $\left(<1 \mathrm{~km}^{2}\right)$ study area (Phillips et al., 2004), in this study we examine the problem at a broader scale, and from the perspective of the partitioning of flow. We follow standard practice in hydrology and fluvial geomorphology in partitioning surface flow into concentrated (gullies or stream channels) and diffuse (sheet and rill) flow. It is also standard in karst hydrology to distinguish among diffuse recharge and point inputs, the latter related to concentrated subsurface flow (Dreybrodt, 1988).

Each unit of effective precipitation (precipitation minus evapotranspiration) is conceptualized as being partitioned in two binary ways: surface flow vs. groundwater recharge, and concentrated vs. diffuse flow. Using Q to indicate surface and $\mathrm{q}$ subsurface flow, and subscripts $\mathrm{c}$ and $\mathrm{d}$ to indicate concentrated and diffuse flows, one unit of effective precipitation is partioned thus:

$Q_{c}+Q_{d}+q_{c}+q_{d}=1$

Given a finite moisture input, Eq. (4) and general mass balance considerations indicate that there is "competition" in the sense that all flow must be either surface or subsurface, so that water which infiltrates, for instance, cannot run off on the surface. In either case, at any given moment concentrated flow (in surface channels or as point recharge or conduit flow) is unavailable for diffuse flow (as sheet and rill flow, diffuse recharge, or Darcian flow). The interactions between the components is thus as shown in Fig. 1. All four components are externally influenced by climate, geology, and other factors, but $q_{d}$ also has self-limiting effects due to the relationship between moisture content, infiltration, and hydraulic conductivity. The maximum flow is limited by saturated hydraulic conductivity, while infiltration is at a maximum when the soil is dry.

Over longer time scales, or with additional components added to the model, different or additional feedbacks are possible, which might affect model stability. This is unsurprising, as stability properties of hydrologic (and other earth surface) systems often change as temporal or spatial scales vary (Loewenherz, 1991; Phillips, 1999; Scheidegger, 1983; Smith and Bretherton, 1972). Our purpose in using the flow partitioning model is to determine whether flow competition dynamics alone are sufficient to account for karst/fluvial divergence.

The model of Fig. 1, translated into an interaction matrix and evaluated by the Routh-Hurwitz criteria, must be unstable, as is readily illustrated by considering feedback at level

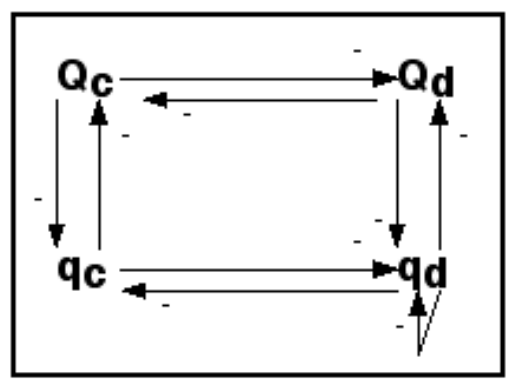

\begin{tabular}{|l|l|l|l|l|}
\hline & $Q_{c}$ & $Q_{d}$ & $q_{c}$ & qd $_{d}$ \\
\hline$Q_{c}$ & 0 & $-a_{12}$ & $-a_{13}$ & 0 \\
\hline$Q_{d}$ & $-a_{21}$ & 0 & 0 & $-a_{24}$ \\
\hline$q_{c}$ & $-a_{31}$ & 0 & 0 & $-a_{34}$ \\
\hline$q_{d}$ & 0 & $-a_{42}$ & $-a_{43}$ & $-a_{44}$ \\
\hline
\end{tabular}

Fig. 1. Flow partitioning model (variables defined in text). The arrows represent the negative (competitive) influences of the flow components on each other, translated into the interaction matrix with elements $a_{i j}$.

two:

$F_{2}=\left(-a_{12}\right)\left(-a_{21}\right)+\left(-a_{13}\right)\left(-a_{31}\right)+\left(-a_{24}\right)\left(-a_{42}\right)$

$+\left(-a_{34}\right)\left(-a_{43}\right)>0$

This instability suggests that landscapes developing from two apparently similar starting points may develop quite different landforms and flow systems as minor initial variations become exaggerated over time. It also suggests that perturbations which affect flow partitioning may have disproportionately large and long-lasting effects - for example, a statechange from a karst to a fluvial-dominated system (or vice versa).

\subsection{The Role of Slope}

The instability indicates that the flow partitioning is sensitive to small perturbations, so that the relative importance of surface, subsurface, concentrated, and diffuse flow is likely to be modified in ways that are disproportionately large and longlived relative to the perturbation. We are particularly concerned with the role of slope, for two reasons. First, in karstprone landscapes there is an inverse relationship between slope and karstification. That is, other things being equal, gentler slopes promote karst development and steeper slopes encourage fluvial action. Areas of low slope significantly above base level tend to develop karst features as water infiltrates toward the local base level (Dreybrodt, 1988; Jennings, 1985; Ford and Williams, 1989; White, 1988). Williams (1985) argued that steep topography can limit the development of karst. The development of the slope, however, may require fluvial processes and incision. Steeper slopes thus promote surface and concentrated as opposed to subsurface and diffuse flow. The second reason for the emphasis on 


\section{Location of Study Area within Kentucky}

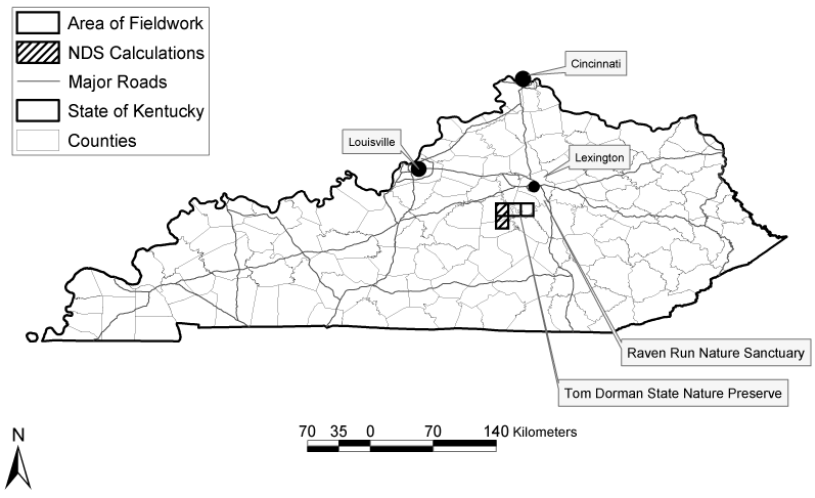

Fig. 2. Study area (boxes) shown on locator map of Kentucky. The two study subareas are indicated by shading, along with major sites of fieldwork.

slope effects is that the study area has experienced extensive downcutting in the Quaternary (see next section), with the attendant localized slope increases.

\section{Study Area and Methods}

\subsection{Study Area}

The study area is in the Kentucky River gorge area of the Inner Bluegrass karst region of central Kentucky, USA. The Kentucky River flows generally northwestward across the Bluegrass (Fig. 2), where it has cut a gorge across limestone bedrock of Middle Ordovician age, locally known as the Palisades. Local relief of $100 \mathrm{~m}$ is common and river-to-cliff or bluff top relief ranges from 61 to $122 \mathrm{~m}$.

Bedrock is comprised of the High Bridge Group and the Lexington Limestone, both Middle Ordovician (Sparks at al., 2001). The Lexington Limestone is dominated by limestone, but includes minor shale beds, though the "shale" contains 50\% or more calcite (Fisher, 1968). The underlying High Bridge Group consists of thick-bedded and massive limestones, some with dolomitized burrows. Bentonites (thin clay-rich volcanic ash layers) are found toward the top of the Group. Bedding in the Lexington Limestone is thinner than in the High Bridge Group. The Kentucky River fault system and a number of minor faults occur in the study area .

In uplands adjacent to the incised modern Kentucky River there are abandoned valleys. These have meandering patterns and often contain either underfit streams or numerious dolines. The valleys have fluvial sand and gravel deposits, with pebbles unrelated to the underlying lithology (Jillson, 1946, 1947, 1948a, 1948b; Sparks et al., 2001). Jillson (1946, 1947, 1948a, 1948b) construed the valleys as a course of the ancestral Kentucky River, an interpretation we accept. The upland palaeochannels are estimated to be about

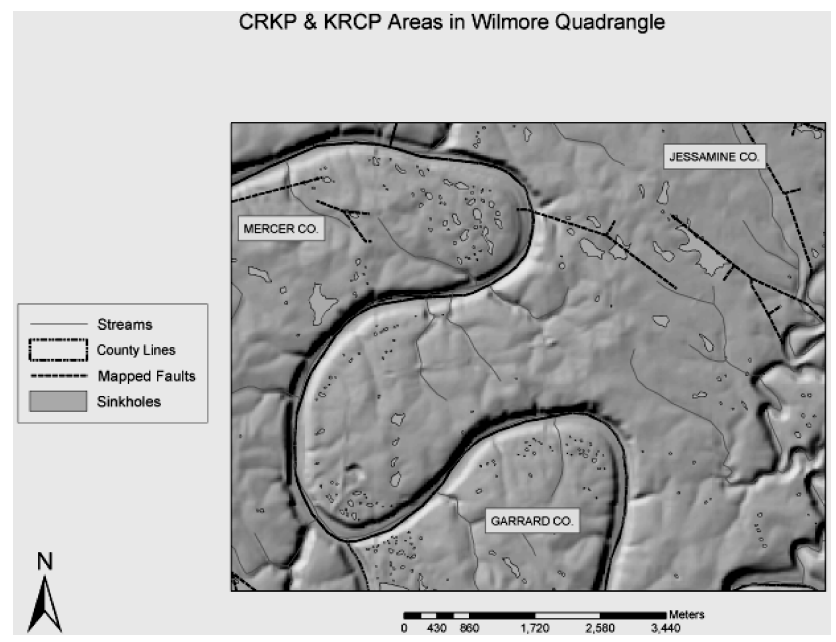

Fig. 3. A portion of the Wilmore quadrangle within the study areas in Jessamine, Mercer, and Garrard Counties, Kentucky. A fluviallydissected CRKP zone is in the middle of the site, with undissected KRCP zones evident surrounding it. Note that while some large depressions are apparently associated with faults, other karst depressions are concentrated on low-slope areas, particularly just inside Kentucky River meander bends.

1.5 million years old (Andrews, 2004; Phillips et al., 2004). The subsequent incision is most likely a result of base-level changes resulting from glacial modification of downstream drainage systems (Teller and Goldthwait, 1991). Because the palaeochannels predate incision of the modern river, the incision of the modern Kentucky, and thus much of the related karst development, is less than 1.5 million years old.

Within the Kentucky River gorge area, uplands tend to either be strongly fluvially dissected, with no obvious surface evidence of dolines or other karst features, or dominated by dissolutional landforms, with little or no evidence of channelized surface flow (Fig. 3). Previous studies (Phillips et al., 2004; Sparks et al., 2001; Thrailkill, 1982) have shown that there are indeed relationships between karstification (density of karst landforms and solutional depressions) and lithology, though within the study area karst-rich landscapes are found in a variety of lithologies, and even the most karstprone limestones do not always have dense - or any-karst depressions. Likewise, many large sinks or karst-rich areas are associated with fractures, and with Kentucky River palaeochannels - but many fractures and palaeochannels are not karstified, and many karst-rich landscapes are not associated with these features. Structure, lithology, and palaeolandforms are clearly important in determining the hydrology and geomorphology of the region, but are also inadequate to fully explain landscape evolution and hydrologic fluxes.

\subsection{Methods}

The stability of the system shown in Fig. 1 was analyzed using the Routh-Hurwitz Criteria, as described in Sect. 2. Other methods are described below. 


\subsubsection{Data Collection}

Within the Kentucky River Gorge study area, an approximately $700 \mathrm{~km}^{2}$ site was selected in and around Tom Dorman Nature Preserve (Fig. 4). This was divided into two subareas based on data availability. One half, corresponding to the Wilmore and Little Hickman U.S. Geological Survey (USGS) 7.5-min topographic quadrangles, was the locus for a series of field visits that focused on publicly accessible facilities such as Tom Dorman Nature Preserve and Raven Run Nature Preserve. However, for the computerized analysis problems were encountered in source data for these two quadrangles. Two quadrangles, the Harrodsburg (L39) and Danville (M39) US. Geological Survey (USGS) 7.5-min topographic quadrangles, located immediately west of these were therefore utilized. For this latter study area, the following data sets were acquired for analysis in a geographical information system (GIS):

- Sinkholes (Sinkholes16.shp from the Kentucky Geological Survey; KGS): This data layer consists of sinkholes derived from closed depressions on contours originating in USGS 1:24 000 digital line graph (DLG) data sets.

- Streams (Streams16.shp, KGS): This consists of "blueline" streams and rivers originating in USGS 1:24000 DLG data sets.

- Digital Elevation Models (L39_DEM.E00 and M39_DEM.E00 from USGS): These Digital Elevation Models correspond to the two 1:24000 topographic quadrangles of the study area.

This study area was then divided into $100 \mathrm{~m}^{2}$ cells using the GIS. The cell size was chosen based on the resolution available in the input data, most critical with the DEMs. The minimal cell size must include at least two adjacent DEM posts, situated $30 \mathrm{~m}$ apart, to meaningfully indicate slope. Selecting a cell size approximately three times this distance ensures that this minimum criterion is met, even when posting departs from uniform placement due to terrain break lines. The generated grid contained a total of 355200 cells $\left(355.2 \mathrm{~km}^{2}\right)$, of which 26055 were subsequently discarded from analysis due to extending beyond the two-quadrangle study area or due to missing data. Each of the 329145 remaining cells was subsequently classified as to slope and degree of karstification as described below.

Karstification Index. An index of karstification was compiled by feature overlay methods, based on mapped drainage features, closed depressions, and related terrain features. These resulted in four key indicators of relative karstification, each of which was coded true or false:

1. Stream - One or more stream segments lie within the cell

2. Stream Buffer-One or more elements of a $100 \mathrm{~m}$ buffer generated around each stream lies within the cell. (A buffer of $100 \mathrm{~m}$ was chosen for stream features to adjust for variable widths of streams and valleys)

\section{Terrain in Wilmore and Little Hickman Quadrangles}

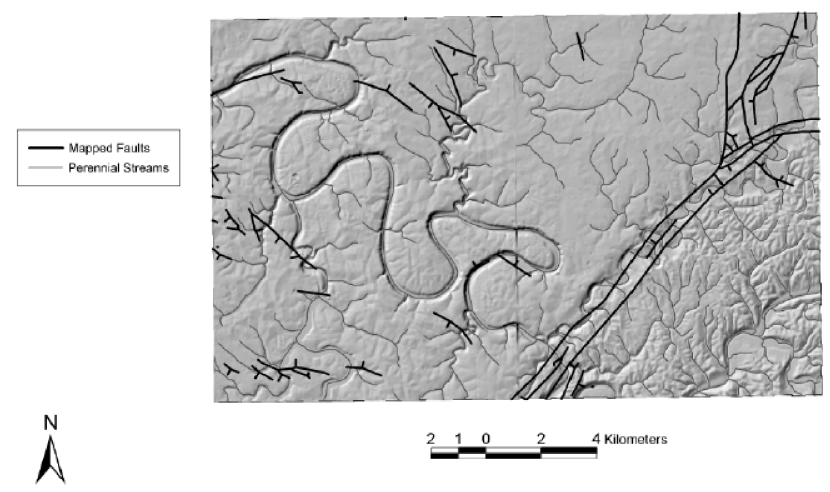

Fig. 4. Terrain with the area of the Wilmore and Little Hickman quadrangles. The base is a shaded relief map produced from digital elevation models.

Table 1. This classification table is a variant of a truth table, which spells out how the karstification score is related to the four input characteristics (has stream, has stream buffer, has karst feature, has karst buffer). T, F, represent true and false, respectively.

\begin{tabular}{lllll}
\hline K or C & Has Stream & Has SBuff & Has Karst & Has KBuff \\
\hline 1 & $\mathrm{~F}$ & $\mathrm{~T}$ & $\mathrm{~T}$ & $\mathrm{~T}$ \\
1 & $\mathrm{~F}$ & $\mathrm{~F}$ & $\mathrm{~T}$ & $\mathrm{~T}$ \\
1 & $\mathrm{~F}$ & $\mathrm{~F}$ & $\mathrm{~T}$ & $\mathrm{~F}$ \\
2 & $\mathrm{~T}$ & $\mathrm{~F}$ & $\mathrm{~T}$ & $\mathrm{~T}$ \\
2 & $\mathrm{~F}$ & $\mathrm{~T}$ & $\mathrm{~T}$ & $\mathrm{~F}$ \\
2 & $\mathrm{~F}$ & $\mathrm{~F}$ & $\mathrm{~F}$ & $\mathrm{~T}$ \\
3 & $\mathrm{~T}$ & $\mathrm{~T}$ & $\mathrm{~T}$ & $\mathrm{~T}$ \\
3 & $\mathrm{~T}$ & $\mathrm{~T}$ & $\mathrm{~T}$ & $\mathrm{~F}$ \\
3 & $\mathrm{~T}$ & $\mathrm{~F}$ & $\mathrm{~T}$ & $\mathrm{~F}$ \\
3 & $\mathrm{~F}$ & $\mathrm{~T}$ & $\mathrm{~F}$ & $\mathrm{~T}$ \\
3 & $\mathrm{~F}$ & $\mathrm{~F}$ & $\mathrm{~F}$ & $\mathrm{~F}$ \\
4 & $\mathrm{~T}$ & $\mathrm{~T}$ & $\mathrm{~F}$ & $\mathrm{~T}$ \\
4 & $\mathrm{~T}$ & $\mathrm{~F}$ & $\mathrm{~F}$ & $\mathrm{~T}$ \\
4 & $\mathrm{~F}$ & $\mathrm{~T}$ & $\mathrm{~F}$ & $\mathrm{~F}$ \\
5 & $\mathrm{~T}$ & $\mathrm{~T}$ & $\mathrm{~F}$ & $\mathrm{~F}$ \\
5 & $\mathrm{~T}$ & $\mathrm{~F}$ & $\mathrm{~F}$ & $\mathrm{~F}$ \\
\hline
\end{tabular}

1 - Karst dominated.

2 - Karst dominated, with observable fluvial features.

3 - Mixed characteristics.

4 - Fluvial dominated, with observable karst features.

5 - Fluvial dominated.

0 - Unknown or not classified.

3. Karst - One or more karst features (sinkholes) lie within the cell.

4. Karst Buffer - One or more elements of a $50 \mathrm{~m}$ buffer generated around each karst feature lies within the cell.

A truth table (Table 1) was generated for each combination of these four indicators, which was then used to create a final 
classification for each cell (subsequently referred to as the karstification index or pattern for brevity).

Slope Index. Slope computations from the DEM data were used to classify the cells as to average slope. This classification was automated by converting the DEM into a slope grid, then reclassifying the resulting polygons using a domain of:

1. Flat ( $<5 \%$ slope gradient)

2. Gently sloping (5 to $10 \%$ )

3. Moderate slope (10 to $15 \%$ )

4. Moderately steep (15 to $30 \%$ )

5. Steep ( $>30 \%$ slope).

The index grid cells were then classified on the same domain by performing a polygon overlay of the grid cells onto the slope polygons, then calculating a weighted average slope for the grid cells.

In addition to the GIS data, detailed field observations were made in a KRCP zone in the Tom Dorman nature preserve, and in a CRKP zone at Raven Run Nature Preserve, along with a general field reconnaissance of the entire Kentucky River gorge area.

\subsubsection{Data Analysis}

If any of the five landscape states represented by the karstification index was equally likely in any cell, the distribution would be random. This was tested using Shannon's entropy

$H=-\sum\left[P_{i}\left(\ln P_{i}\right)\right]$

where $P_{i}$ is the probability of the $i$ th value of the classification which is taken as the proportion of cells of type $i$.

The maximum possible entropy $H_{\max }$ occurs in a random pattern when all values have an equal probability of occurrence, $1 / n$, where $n$ is the number of classes $(n=5$ in this case).

$H_{\max }=\ln (n)$.

This is, of course, a reference condition, as equiprobability of landscape types across variations in regional slope, lithology, and structure is unrealistic.

While we hypothesize a slope control over karst vs. fluvial development, we recognize the causality may run in either direction (for instance, cells with fluvial features might have steeper slopes associated with valley sides). But entropy can be used to estimate constraints independent of hypothesized causality - that is, we can determine the extent to which uncertainty in the karstification index $(\mathrm{K})$ is reduced by a knowledge of slope class (s):

$$
\begin{gathered}
n \quad m \\
H_{s}(K)=1 /\left[N \ln \left\{\Pi\left(f_{i} ! / \Pi f_{i j} !\right)\right\}\right] \\
i=1 \quad j=1
\end{gathered}
$$

where $N$ is the number of cells, $f_{i}$ the occurrence of karstification index class $i, f_{j}$ the occurrence of slope class $j$, and $f_{i j}$ the joint occurrence of karstification class $i$ and slope class $j$.

The factorials are unmanagably large, but a reliable estimate is given by

$H_{S}(K)=1 /\left\{N \ln \left[\Sigma f_{j} \ln f_{j}-\Sigma f_{i} \ln f_{i}\right]\right\}$.

If $H_{S}(K)<H(K)$, the uncertainty and entropy have been reduced by a factor $(r)$ associated with the constraint $s$ (slope) exerts on $K$ (karstification):

$$
\begin{aligned}
& r=\left(e^{N H(K)}\right) /\left(e^{N H a(K)}\right), \text { or } \\
& \ln r=N H(K)-N H_{S}(K)
\end{aligned}
$$

The quantity $\ln r$ is called mutual information, and measures the information transmitted without noise. Significance can be tested using the chi-square statistic, since $\ln \mathrm{r} \sim \chi^{2}$. Entropy reduction is given by $\ln r / N$. The use of mutual information functions in symbolic patterns or sequences of nonlinear dynamical systems is discussed by Li (1990).

The change in Shannon (information) entropy over time is termed the Kolmogorov ( $K$-) entropy. There is a direct link between $K$-entropy and chaos, as $K$-entropy of a dynamical system is equal to the sum of the positive Lyapunov exponents. Thus an increase in entropy over time indicates positive K-entropy, which in turn signifies a positive Lyapunov exponent.

The direction, if not the magnitude, of entropy changes, can be assessed based on field evidence. Phillips (2000), for example, used soil stratigraphic evidence to infer the thinning and thickening trends of weathering profile horizons, and thus whether entropy was increasing or decreasing. By determining whether KRCP and/or CRKP zones are growing (decreasing) at the expense of (due to the expansion of) other landscape types, the direction of entropy change - and thus whether there is positive $K$-entropy - can be determined.

\section{Results}

\subsection{Fluvial and Karst Erosion}

Of the total cells, 329145 had usable data. Landscape class 3 , with no channels or solutional features visible from topographic maps or DEMs, or with a mixture of fluvial and karst features with neither clearly dominant, was by far the most common, comprising nearly $76 \%$ of all cells (Table 2 ). Karst- and fluvial-dominated cells were about equally abundant. Class 2 (fluvially-dominated but with karst present) and class 4 (karst-dominated but channels present) each comprised about $9 \%$ of the cells. Completely karst-dominated (KRCP) and fluvially-dominated (CRKP) cells accounted for 2.4 and $3.5 \%$ of the total, respectively.

Almost 84 percent of the cells were in the lowest slope class $(<5 \%)$. Both these cells and karstification class 3 cells were concentrated in upland areas away from the Kentucky River. Most of the remainder of the cells were in the second slope class (5 to 10\%). The upper 3 slope classes each 
Table 2. Classification of landscape cells (number of cells in each class).

\begin{tabular}{lllllll}
\hline \multicolumn{7}{c}{ Karst/fluvial classification* } \\
\hline Slope Class & Karst & Karst-dominated & Karst \& fluvial & Fluvial dominated & Fluvial & Total \\
\hline$<5 \%$ & 7,018 & 26607 & 211974 & 21163 & 8564 & 275326 \\
$5-10 \%$ & 749 & 3546 & 32828 & 5540 & 2191 & 44854 \\
$10-15 \%$ & 25 & 187 & 2701 & 1717 & 567 & 5207 \\
$15-30 \%$ & 1 & 116 & 1387 & 1271 & 287 & 3062 \\
$>30 \%$ & 0 & 25 & 440 & 212 & 19 & 696 \\
Total & 7793 & 30491 & 249330 & 29903 & 11628 & 355200 \\
\hline
\end{tabular}

*Karst, fluvial classes are completely dominated by karst or fluvial features with no evidence of the other. Karst- and fluvial-dominated classes have evidence of both karst and fluvial features, but one is clearly dominant. The karst \& fluvial class has no topographic evidence of erosional features of any kind, or karst and fluvial features in equal proportion.

accounted for less than two percent of cells (Table 2). The steepest slope cells, not unexpectedly, are in the immediate vicinity of the gorge or of larger Kentucky River tributaries.

\subsection{Channel Rich Fluvially Dissected Zones}

Fluvially dissected, channel-rich and karst-poor (CRKP) zones were observed in the field in several locations, particularly in the vicinity of Boone Creek, Howard's Creek, and Raven Run. These Kentucky River Tributaries are characterized by steep channel gradients with numerous nickpoints and waterfalls, associated with differences in resistance as downcutting encounters different stratigraphic layers of the Lexington Limestone and the High Bridge Group.

Small-scale limestone weathering features are evident on exposed bedrock surfaces, and weathering cavities, cutters, and other dissolution features are common. However, karst drainage features such as sinkholes are rare or absent, and are generally small when encountered. Ascending to the upper reaches of these streams the CRKP (karstification class 5) landscapes merge into fluviokarst landscapes with varying degrees of both fluvial and karst features (karstification classes 2, 3, 4).

Nickpoints and active channel incision are indicative of an actively expanding channel system with headward growth. Thus these tributary basins, downcutting in response to Quaternary incision and entrenchment of the Kentucky River, are expanding CRKP zones at the expense of mixed fluviokarst landscape types (Fig. 5). Similar observations and conclusions have been drawn by others working in the Kentucky River gorge area (Andrews, 2004; Jillson, 1946, 1947, 1948a, 1948b; Phillips et al., 2004).

\subsection{Karst Rich Zones}

A landscape with little or no channelization or evidence of surface flow but with abundant karst sinkholes was examined at Tom Dorman Nature Preserve (Fig. 6). On the eastern side of the Dorman site, there is a line of large sinkholes and an abundance of other sinks, with typical median surface diameters ranging from a few meters to $>100 \mathrm{~m}$. There are
CRKP Area at Raven Run
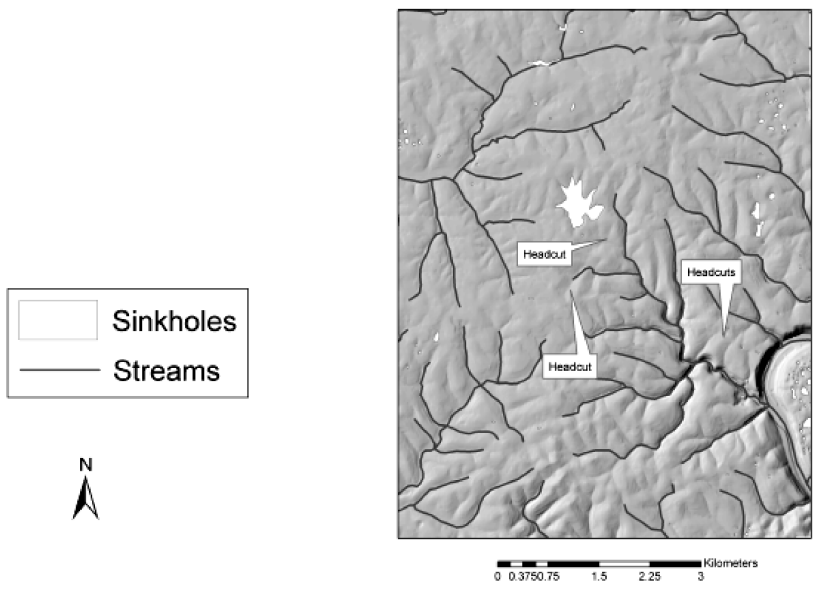

Fig. 5. Channel-rich, karst poor area of Raven Run. Arrows show examples of location where field evidence (active headcuts) shows conversion of mixed fluviokarst or minimally-eroded areas into fluvially-dissected.

no permanent channels, and the few ephemeral channels are short and lead directly into sinkholes. The morphology of the sinks, and shallow exploration of the open swallets in some suggests that they are collapse features connected to a subsurface cavern.

Sediments in the depressions, vegetation indicators, and recent slope failures within some sinks show that they are actively growing features. They are in close proximity to a mixed fluviokarst landscape on the west side of the preserve. Evidence is consistent with a subsurface fracture enlarging on concert with Kentucky River downcutting, resulting in growth and intensification of surficial karst depressions. We cannot determine definitively that a more fluvially-influenced landscape once occupied the site, but palaeochannel deposits do indicate that the area was once within the Kentucky River channel/floodplain.

More generally, areas inside of Kentucky River meander bends are often KRCP zones (and are never CRKP). One 


\section{Geomorphology of Tom Dorman Nature Preserve}

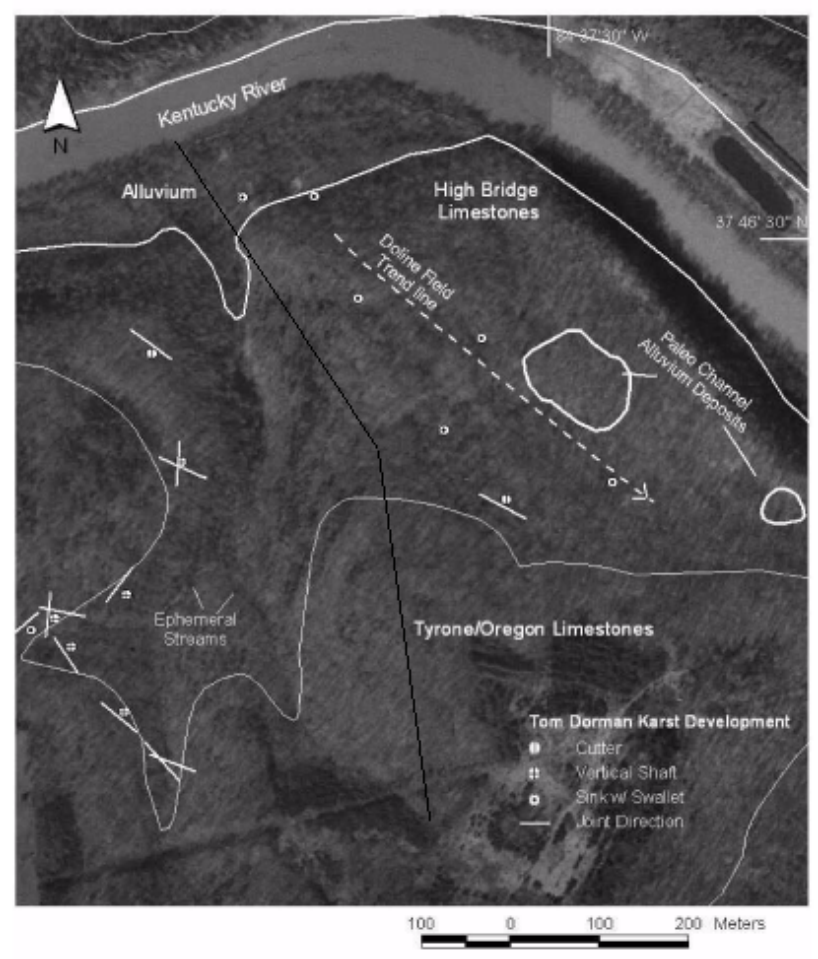

Fig. 6. Geomorphological map of Tom Dorman Nature Preserve, on digital orthophotoquad base. The black line separates the CRKP zone to the left from the KRCP area to the right. Modified from Fig. 7 of Phillips et al. (2004); field mapping by Linda Martin.

possibility is that these areas were karstified before downcutting commenced, and have simply been preserved as the local base level was lowered. However, in many cases active karst sinks are observed not only on the uplands, but also on lower, younger terraces, indicating that karstification has continued to be active throughout the Quaternary. Also, in some cases the KRCP zones conincide with palaeochannel locations, indicating a fluvial-to-karst transition.

Thus the field evidence suggests that at least some KRCP zones (karstification class 1) are growing at the expense of class 2, 3, and 4 landscapes. Growth at the expense of class 5 (completely fluvially dissected) is theoretically possible, but we did not observe any field evidence indicating this. These observations and interpretations are consistent with others working in the central Kentucky karst region (MacQuown, 1967; Phillips et al., 2004; Taylor, 1992; Thrailkill, 1984).

\subsection{Entropy}

The entropy of the karstification pattern is 0.855 , which is about $53 \%$ of the maximum value for a five-part classification (entropy of the slope classes is about 0.54). The entropy of the karstification index as constrained by slope is $H_{S}(K)=0.721$. The mutual information $\ln r=44105$, associated with an entropy reduction of 0.134 .
Because field evidence suggests the growth of both KRCP and CRKP zones at the expense of other landscape types, potential entropy changes can be estimated. Because karstification classes 1 and 5 are small, growth of these at the expense of other classes tends to increase entropy. For example, a $10 \%$ increase in the number of class 1 and 5 cells entirely at the expense of class 3 increases $H(K)$ to 0.874 . If it is assumed that the transitions are entirely class 4 to 5 and 2 to $1, H(K)$ increases to 0.862 . If the increase occurs at the expense of classes 2,3 , and 4 in proportion to their current abundance, $H(K)$ increases to 0.872 . These examples serve to illustrate that current late Holocene landscape evolution trends are in the direction of increasing entropy, and thus $K$-entropy $>0$.

\section{Discussion}

Fluviokarst landscapes are characterized by a combination of flow regimes involving surface and subsurface flow, either of which may be either concentrated or diffuse. There are mutual adjustments between these hydrologic flows and landforms which may both reflect and direct the partitioning of moisture among the flow regimes. If the partitioning of effective precipitation is considered in terms of competition (in the sense that water allocated to one mode is unavailable to the others), the system is dynamically unstable. Because the stability analysis is based on a qualitative model, the results are robust to variations in the specific quantitative partitioning. This instability indicates deterministic chaos, indicating that the flow partitioning system is sensitive to minor variations in initial conditions or small perturbations.

The conceptual model was developed in an effort to explain the complex spatial pattern of karst and fluvial landforms in central Kentucky. Some karst drainage features (chiefly sinkholes) are clearly related to faults, fractures, and structural features, or to coarse-bedded Kentucky River palaeochannels. However, many karst depressions are unrelated to these controls, and many of the geologic controls which appear to promote karstification in some cases often have no evidence of surficial karst, and may sometimes have fluvial landforms and surface-dominated drainage. Analogous observations may be made for channels and fluvial landforms. The wide variation in (or lack of) relationships between karst or fluvial development and geologic controls, together with the fact that karst-fluvial transitions are possible in carbonate terranes, leads to the suspicion that instability and chaos may play a role. The analysis here focussed on slope, due to the possibility that geologically recent slope adjustments in response to Kentucky River incision may be related to KRCP/CRKP divergence.

One unexpected outcome of the analysis is the large proportion of the landscape with minimal karst or fluvial development - the associated category of the landscape classification index comprised $76 \%$ of the study area, and the end-members only about six percent. In retrospect, we did not anticipate this because of our tendency to focus on 
the most highly eroded (by fluvial or solutional processes) areas, and by the predominance of our field observations near the Kentucky River, where both KRCP and CRKP zones are more common. The incision of the river and associated change in hydrologic base level is the single most important factor driving both fluvial and karst development in the recent geological past, so it is not surprising that large areas away from the channel have been minimally influenced thus far. Confining our analysis to a swath along the river valley would have increased the relative proportion of the end-member categories in the landscape classification and decreased the proportion occupied by minimally eroded terrain, but would not have changed the qualitative outcome or the fundamental implications of the analysis.

The flow partitioning model is based entirely on a notion of competition for moisture; e.g. that an increase in one component (for example surface sheet and rill flow) must result in a decrease in at least one of the others (and vice-versa for a decrease). Thus an increase in sheet and rill flow must come at the expense of diffuse groundwater or soil moisture recharge or channelized surface runoff. There is no relationship between concentrated surface and diffuse subsurface flow. This is reasonable within the study area as loss of channelized flow to the subsurface occurs entirely (in our field observations) via swallets, sinks, and solutionally-enlarged fractures. Where return flow to streams occurs it is overwhelmingly via karst conduits. There are also no links connecting diffuse surface flow and concentrated groundwater flow. There is no plausible link from conduit flow or point recharge to overland runoff. It is conceivable that sheet and rill flow could be captured by solutional cavities. However, we have never observed this in the field, and in the study area any links are mediated by epikarst. That is, infiltration and diffuse recharge into the soil occurs, which may then be directed into conduits (accounted for by the $q_{d}$ to $q_{c}$ link).

It could be argued in some contexts that there could be positive relationships in the conceptual model - for example, that in the case of a losing stream (local terminology for a stream which discharges into a sink or swallet) an increase in runoff would lead to a corresponding increase in point recharge. Or, that a decline in diffuse surface runoff would lead to a corresponding decline in concentrated surface flow or diffuse recharge. However, in the context of the model as conceptualized here - partitioning a single unit of effective precipitation via competition - the negative links must hold. Thus the point recharge in a losing stream must come at the expense of channel flow, for instance; or a decrease in the proportion of overland flow must be accounted for by increases in channelized surface flow and/or diffuse recharge.

This approach does not account for changes in climatic moisture regimes or their accomodation. Climate change has occurred during the Quaternary, and has clearly influenced at least some aspects of the hydrology and geomorphology of the study area. We do not seek to minimize the importance of these changes, but rather to show that the hydrologic regime in the study area is highly sensitive to minor variations even when the climatically-driven moisture regime is constant; that fluvial/karst transitions can occur independently of externally-driven hydrologic change.

While instability in the flow-partitioning model provides a plausible explanation for the complex spatial pattern in the landscape, and for divergence into karst- and fluviallydominated zones, it does not demonstrate divergent, chaotic landscape evolution. This is accomplished by showing that the enlargement of KRCP and CRKP zones, indicated by field evidence, is occurring at the expense of mixed karst/fluvial landscapes. This in turn must increase the entropy, indicating finite positive Kolmogorov entropy. The $K$ entropy is associated with a positive Lyapunov exponent, and thus with chaos and dynamical instability.

The chaotic nonlinear dynamics indicated in the evolution of fluviokarst landscapes of central Kentucky are intertwined with non-chaotic deterministic effects of controls such as structure, lithology, and palaeolandforms. While this work was inspired by the fact that the latter are inadequate to explain the hydrology and geomorphology of the study area, the reverse is also true. That is, the landscape cannot be satisfactorily understood by relying on complexities in flow partioning alone, without consideration of geologic controls, environmental change, and other factors.

The landscape divergence into strongly karst- or fluviallydominated sectors has long been noted by Kentucky geoscientists, who generally operate under a tacit assumption that, given sufficient local detail, each individual case can be explained on the basis of fundamental principles of fluvial and karst geomorphology. This attitude involves an implicit assumption that unseen variations are sufficient to result in different evolutionary pathways. Nonlinear dynamical systems theory in this case provides a theoretical justification for this assumption and at least a phenomenological explanation for how minor variations or changes can lead to, in some cases, dissected gorges or sinkhole plains in originally similar landscapes.

\section{Conclusions}

In fluviokarst landscapes flow may be partitioned into its surface and subsurface components, and into diffuse and concentrated flow above or below ground. In the context of partitioning a unit of effective precipitation, these relationships are competitive, in the sense that a change in the proportion of flow in any pathway must be accompanied by a change in the opposite direction in at least one other pathway. The dynamically unstable, chaotic nature of this system is a plausible explanation for the divergence of the landscape in a fluviokarst region of central Kentucky into depressionrich, unchannelled karst-rich and channel-poor (KRCP) and strongly fluvially dissected channel-rich karst-poor (CRKP) zones, which often occurs with no relationship to observable environmental controls. The chaotic interrelationships between diffuse surface runoff, channelized surface flow, diffuse recharge, and point recharge imply that small changes 
in the partitioning are likely to have disproportionately large and long-lived impacts, reflected in landforms.

In the Kentucky River gorge, rapid Quaternary incision has resulted in local slope changes which should induce instability in the flow partitioning system. A GIS-based landscape classification scheme showed that there is a statistically significant relationship between slope gradients and the degree of karstification or fluvial dissection. Geomorphic interpretation of landforms in the river gorge area indicates that CRKP and $\mathrm{KRCP}$ zones are growing at the expense of other landscape classes. This results in an increase in entropy, indicating finite positive Kolmogorov entropy, a characteristic of a dynamically, unstable, chaotic system. Results support the hypothesis that divergent landscape evolution is linked to the complex nonlinear dynamics of low partitioning. The hydrologic regime in the study area, the dominant driver of geomorphic evolution, is highly sensitive to minor variations even when the climatically-driven moisture regime is constant.

Acknowledgements. Ideas, encouragement, fieldwork, and data were provided by a number of colleagues at the University of Kentucky, particularly W. M. Andrews Jr., L. Martin, and V. Nordberg. Plangraphics, Inc. (Frankfort, KY) graciously provided use of their hardware, software, and facilities for some of the analyses.

Edited by: B. Sivakumar

Reviewed by: A. C. W. Baas and E. C. Rankey

\section{References}

Andrews Jr., W. M.: Geologic Evolution of the Kentucky River, PhD Dissertation, University of Kentucky, Lexington, 2004.

Andronova, N. G. and Schlesinger, M. E.: The application of causeand-effect analysis to mathematical models of geophysical phenomena, 2. Stability analysis, J. Geophys. Res., 97D, 5911-5919, 1992.

Baker, A. and Brunsdon, C.: Non-linearities in dripwater hydrology: an example from Stump Cross Caverns, Yorkshire, J. Hydrol., 277, 151-163, 2003.

Cesari, L.: Asymptotic Behavior and Stability Problems in Ordinary Differential Equations, Springer, Berlin, 1971.

Dietrich, W. E., Wilson, C. J., Montgomery, D. R., McKean, J., and Bauer, R.: Erosion thresholds and land surface morphology, Geol., 20, 675-679, 1992.

Dreybrodt, W.: Processes in Karst Systems: Physics, Chemistry, and Geology, Springer, Berlin, 1988.

Fisher, I. S.: Interrelation of mineralogy and texture within an Ordovician Lexington Limestone section in central Kentucky, J. Sed. Pet., 38, 775-784, 1968.

Ford, D. C. and Williams, P. W: Karst Geomorphology and Hydrology, Unwin Hyman, London, 1989.

Islam, M. N. and Sivakumar, B.: Characterization and prediction of runoff dynamics: a nonlinear dynamical view, Adv. Water Resour., 25, 179-190, 2002.

Jennings, J. N.: Karst Geomorphology, Basil Blackwell, New York, 1985.
Jillson, W. R.: The Nonesuch Abandoned Channel of the Kentucky River - A Study in Pliocene Drainage, Physiography, and Geology, Roberts Printing Co., Frankfort KY, 1946.

Jillson, W. R.: The Warwick Abandoned Channel of the Kentucky River - A Study in Pliocene Drainage, Physiography, and Geology, Roberts Printing Co., Frankfort KY, 1947.

Jillson, W. R.: The Hickman Abandoned Channel of the Kentucky River - A Study in Pliocene Drainage, Physiography, and Geology, Roberts Printing Co., Frankfort KY, 1948a.

Jillson, W. R.: The Pleasant Hill Abandoned Channel of the Kentucky River - A Study in Pliocene Drainage, Physiography, and Geology, Roberts Printing Co., Frankfort KY, 1948 b.

Lall, U., Sangoyami, T., and Abarbanel, H. D. I.: Nonlinear dynamics of the Great Salt Lake: nonparametric short-term forecasting, Water Resour. Res., 32, 975-985, 1996.

Li, W: Mutual information functions versus correlation functions, J. Stat. Phys, 60, 823-837, 1990.

Loewenherz, D. S.: Stability and the initiation of channelized surface drainage: a reassessment of the short wavelength limit, J. Geophys. Res., 96B, 8453-8464, 1991.

MacQuown Jr., W. C.: Factors Controlling Porosity and Permeability in the Curdsville Member of the Lexington Limestone. Research Report No 7, University of Kentucky Water Resources Institute, Lexington, Ky, 61 pp, 1967.

Phillips, J. D.: Earth Surface Systems: Complexity, Order, and Scale, Basil Blackwell, Oxford, 1999.

Phillips, J. D.: Signatures of divergence and self-organization in soils and weathering profiles, J. Geol., 108, 91-102, 2000.

Phillips, J. D., Martin, L. L., Nordberg, V. G., and Andrews, W. M.: Divergent evolution in fluviokarst landscapes of central Kentucky, Earth Surf. Proc. Landf., 29, 799-819, 2004.

Porporato, A. and Ridolfi, L.: Nonlinear analysis of river flow time sequences, Water Resour. Res., 33, 1353-1367, 1997.

Puccia, C. J. and Levins, R.: Qualitative Modeling of Complex Systems, Harvard University Press, Cambridge, MA, 1985.

Scheidegger, A. E.: Instability principle in geomorphic equilibrium, Z. Geomorph. 27, 1-19, 1983.

Scheidegger, A. E.: Theoretical Geomorphology (3rd ed.), Springer, Berlin, 1991.

Sivakumar, B.: Chaos theory in hydrology: important issues and interpretations, J. Hydrol., 227, 1-20, 2000.

Sivakumar, B.: Chaos theory in geophysics: past, present, and future, Chaos Sol. Fract., 19, 441-462, 2004.

Slingerland, R.: Qualitative stability analysis of geologic systems with an example from river hydraulic geometry, Geol., 9, 491493, 1981.

Smith, T. R. and Bretherton, F. P.: Stability and the conservation of mass in drainage basin evolution, Water Resour. Res., 8, 15061529, 1972.

Sparks, T. N., Dever, G. R., and Anderson, W. H.: Geologic map of the Harrodsburg $30 \times 60$ minute quadrangle, central Kentucky, Kentucky Geological Survey, Series XII, Geologic Map Series No. 1, 1 sheet, 1:100 000, 2001.

Taylor, C. J: Ground-Water Occurrence and Movement Associated with Sinkhole Alignments in the Inner Bluegrass Karst Region of Central Kentucky, M.S. Thesis, University of Kentucky, Lexington, 1992.

Teller, J. T. and Goldthwait, R. P.: The Old Kentucky River; A major tributary to the Teays River, in Geology and Hydrogeology of the Teays-Mahomet Bedrock Valley System, Geological Society of America Special Paper 258, Boulder, CO, 29-41, 1991. 
Thrailkill, J.: Groundwater in the Inner Bluegrass Karst Region, Kentucky, Research Report No. 136, Water Resources Research Institute, University of Kentucky, Lexington, 1982.

Thrailkill, J.: Hydrogeology and Environmental Geology of the Inner Bluegrass Karst Region, Kentucky, Field Guide for the Annual Meeting of the Southeastern and North Central Sections of the Geological Society of America, Lexington, KY, 1984.

Viles, H. A.: Scale issues in weathering studies, Geomorph., 41, 63-72, 2001.
White, W. B.: Geomorphology and Hydrology of Karst Terrains, Oxford University Press, New York, 1988.

Williams, P. W.: Subcutaneous hydrology and the development of doline and cockpit karst, Z. Geomorph., 29, 463-482, 1985.

Zhou, Y., Ma, Z., and Wang, L.: Chaotic dynamics of the flood series in the Huaihe River basin for the last 500 years, J. Hydrol., 258, 100-110, 2002. 